\title{
Deep-Sea Benthic Foraminiferal Distribution in South West Indian Ocean: Implications to Paleoecology
}

\author{
Nadimikeri Jayaraju ${ }^{1}$, Balam Chinnapolla Sundara Raja Reddy ${ }^{2}$, Kambham Reddeppa Reddy ${ }^{2}$, \\ Addula Nallappa Reddy ${ }^{3}$ \\ ${ }^{1}$ Department of Geology \& Geoinformatics, Yogi Vemana University, Kadapa, India \\ ${ }^{2}$ Department of Geology, Sri Venkateswara University, Tirupati, India \\ ${ }^{3}$ ONGC Regional Geoscience laboratory, Chennai, India \\ E-mail:nadimikeri@gmail.com \\ Received May 14, 2010; revised June 13, 2010; accepted July 11, 2010
}

\begin{abstract}
Five grab samples from the southwestern part of the Indian ocean were collected by ORV Sagar Kanya during the third expedition to the southern Indian ocean in June 2009. The sediment samples have been analyzed and recorded 36 benthic foraminiferal species belonging to 21 genera and 3 suborders. All the species were taxonomically identified, SEM photographed and illustrated. Deep sea-benthic foraminiferal species at different locations of South of West India Ocean (3150-4125 m water depth) is examined in terms of number of species (n) and diversity (d). The observed depth ranges of benthic foraminifera have been documented to recognize their bathymetric distribution. The valves of these parameters reached their maximum at $3190 \mathrm{~m}$ water depth. Productivity continued in the Indo-Pacific Ocean (the biogenic boom) and the Oxygen minimum zone (OMZ) intensified over large parts of Indian Ocean continually. The diversity values show more abrupt trend as depth increases. Species like Epistominella exigua and Pullenia bulloides occur at both 3150 $\mathrm{m} \& 3465 \mathrm{~m}$ depths indicating depth persistence. Further, Oridorsalis umbonatus and Melonis sphaeroides occur at both $3150 \mathrm{~m} \& 3465 \mathrm{~m}$ depths. Species like Gyroidina sp an indicate of low oxygen environment and Uvigerina hispida-costata indicative of high organic carbon are found to occur at $3150 \mathrm{~m} \& 3740 \mathrm{~m}$ respectively. Factor analysis and Pearson correlation matrix was performed on foraminiferal census data of 10 highest ranked species which are present in at least one sample. 3 factors were obtained accounting for $72.81 \%$ of the total variance. Thus the study suggests that fluctuations in species diversity at the locations of the present study were related to changes in productivity during the geological past. Further, the faunal data do indicate the early Holocene Indian Ocean was influenced by increased ventilation perhaps by North Atlantic deep water and or circumpolar deep waters.
\end{abstract}

Keywords: Paleoecology, Benthicforaminifera, Holocene, Indian Ocean

\section{Introduction}

Considerable amount of work has been done to understand Paleoecology, Paleoclimatic and Paleoocenographic evolution of the Indian Ocean during Pleistocene and Holocene using faunal data [1,2]. Benthic foraminifera have substantial scope in paleoecological studies because of their wide distribution in all marine environments and the high fossilization potential of their tests. During the last three decades, several hypotheses have been proposed to explain the distribution patterns and ecologic preferences of this group. For instance, benthic foraminifera have been used extensively to reconstruct the past variability in deep water properties in different ocean basins explained the relationship of various taxa with different levels of deep-sea oxygenation, whereas other studies have related benthic assemblages to the intensity of deep sea currents and ventilation [3]. The fact that benthic foraminifera occupy both epifaunal and infaunal microhabitats led some workers to suggest that sediment and pore water properties may be more important than bottom water conditions in controlling benthic foraminiferal distribution $[4,5]$. Other studies indicate that benthic foraminiferal assemblages are strongly cor- 
related with productivity of the overlying surface waters and the flux of organic matter to the seafloor. Faunal proxy data suggests major changes in the Cenozoic Earths climate forms relatively warm and equable climate in the Paleocene to cold conditions with nearly frizzing temperatures at the poles in the Pliocene [6]. Other changes during this time include those in ocean circulation and productivity and opening and closing of different seaways, including the closure of Tethyan Seaways, including the closure of the Panamanian sea way in the Pliocene [7]. The changes in Antarctic climate during the middle Miocene brought significant changes in ocean surface productivity and oxygenation of deep waters as well [8], which had an impact on the oceans faunal regime. Productivity has increased significantly in all oceans since the late middle Miocene $(\sim 13 \mathrm{Ma})$. The increased glaciations on Antarctica may have intensified wind regimes, loading to widespread open-ocean as well as coastal upwelling over large parts of the Indian, $\mathrm{Pa}-$ cific and Atlantic oceans during the middle Miocene [8]. These productivity events are believed to have triggered the "biogenic bloom" and expansion of the oxygen minimum zone in large parts of the intermediate water of the Indian and Pacific Oceans in the late middle Miocene, about $15 \mathrm{Ma}$ [9]. With these climatic and oceanic changes, deep-sea faunal diversity changed considerably [10].

Availability of nutrients, heterogeneity of the habitat and predation are factors controlling diversity patterns in the deep-sea fauna [10]. It's also observed, low values of species diversity during intervals of environmental instability in the South Indian Ocean in the middle - late Miocene. The high productivity and subsequent microbial decay of organic matter, as well as biotic respiration and other oceanographic factors, lead to extremely low oxygen concentrations in the water column, forming a pronounced oxygen minimum zone (OMZ). Underlying sediments thus contain a geological record of changes in the SW monsoon and OMZ variability [11]. Benthic foraminifera dominate modern ocean floor meiobenthic communities, and in many deep-sea areas, constitute a substantial proportion of the eukaryotic biomass [6]. Due to their high fossilization potential they area very useful in paleooceanograpgic studies. The factors controlling their distribution and abundance are complex and controversial [12], but it appears that two usually inversely related parameters, the flux of organic particulate matter to the sea floor and oxygen concentrations of bottom water and pore waters, are major controlling variables [5]. Other factors which have been suggested (and some of which are not independent of these two) include the type of food supply, bathymetry, sediment type, chemistry of bottom waters current flow intensity and hydrostatic pressure [13]. The supply of organic matter from the euphotic zone to the ocean floor exerts a strong influence on the abundance and biomass of deep-sea benthic fo- raminifera [12] as on other deep-sea organisms.

The composition of benthic foraminiferal assemblages is closely related to the amount and quality of organic matter. Assemblages dominated by the in faunal species Bolivina, Bulimina, Melonis and Uvigerina commonly occur in areas with high, continuous fluxes of organic matter to the sea floor, often associated with reduced bottom water oxygen concentrations. It has been shown, however, that Uvigerina spp are correlated to organic flux and not to low oxygen conditions. To understand the distribution and diversity of benthic foraminifera at different bathymetric levels, the present study was carried out. Benthic foraminiferal species used in the faunal study include, Uvigerina hispida-costata which was dominant during times of high productivity and /or low oxygen and Oridorsalis umbonatus and Quinqueloculina parkeri characteristic of well oxygenated, oligotrophic conditions. Changes in organic flux to the sea floor due to variations in surface productivity modulate deep-sea faunal composition [3]. The amount of organic flux to the sea floor not only depends on surface production but also on the nature of deep-sea column. Well oxygenated deep-sea circulation may cause remineralization of organic carbon resulting in little organic material reaching the sea floor [14]. To understand if the changes in the surface and deep-water column of the tropical condition ocean driven by the Indian ocean climate (monsoon) and deep-sea circulation, an attempt has been made to analyze deep-sea benthic foraminifera from varying depths from (3150 m, $3465 \mathrm{~m}$ and $4125 \mathrm{~m}$ ) (Figure 1). The investigations of benthic foraminifera from south west Indian Ocean provided data on the species distribution and species-specific relations for different depths and areas. These data were later used to distinguish faunistive provinces with the implication to paleoecology. The study presented is aimed at the description of the biogeography and ecology of foraminifera communities based on the data about the dominant species in the tropical Indian Ocean and their occurrences in other areas of the world Ocean.

\section{Materials and Methods}

The study sites are located at different depths of $3150 \mathrm{~m}$ $\left(\mathrm{N} 10^{\circ} \mathrm{E} 65^{\circ}\right) ; 3465 \mathrm{~m}\left(\mathrm{~N} 5^{\circ} \mathrm{E} 65^{\circ}\right) ; 3790 \mathrm{~m}\left(\mathrm{~N} 0^{\circ} \mathrm{E} 65^{\circ}\right)$ and $4125 \mathrm{~m}\left(\mathrm{~N} 5^{\circ} \mathrm{E} 65^{\circ}\right)$ in the South West Indian Ocean. The samples were collected from ORV Sagar Kanya during the third expedition to the southern Indian Ocean by National Center for Antarctica and Ocean Research, (NCAOR) Goa, India, in June, 2009. Sediment samples were transferred into plastic bags and frozen until analysis was carried out. The sediment samples were first washed over a sieve which is an average opening of $0.625 \mathrm{~mm}$. This process helps to wash the sample free of sea water, fixatives, and the fine silt and clay size parti- 
cles. Then a sample was air dried and a suitable sample weighing about 100 grams was obtained by coning and quartering. Samples were spilt using a micro splitter and all benthic foraminifera were picked and identified [15]. Quantitatively, foraminifera could not be separated easily with washing carbon tetra chloride only, so a mixture of Bromoform (specific gravity 2.8) and Acetone (specific gravity 2.4 ) were used to obtain about $15 \%$ crop from the sediment [16]. The residue was examined under a stereo binocular microscope for any left out fauna. Such tests were handpicked by a very fine pointed long haired welted Windsor Newton sable hair brush ("0"). The fauna thus obtained was sorted, counted and identified under a stereo binocular microscope using medium to high magnifications $(6.3 \times 2.5 ; 6.3 \times 4.0)$. The sampling procedures especially sieving and drying reduce the number of the most fragile arenaceous foraminifera (Table 2). Statistical analysis was done by multivariate analysis, correlation analysis was applied to compare and correlate the data generated based on bathymetry [17]. Details of the hydrography, primary productivity and upper ocean mixed layer dynamics are given earlier [18].

To day, the depth of site $4125 \mathrm{~m}\left(\mathrm{~S} 10^{\circ} \mathrm{E} 65^{\circ}\right)$ is close to the calcite Lysocline which, in this part of the Indian Ocean, has been considered to lie between 4000-4200 m and approaches calcite composition depth (CCD). This area was selected because it is a relatively flat area, far from continental shelf to the east and the mid-ocean ridge to the west and so is unlikely to be influenced by strong down slopes or adjective process. Recent sediments in the study area are calcareous oozes with rich biogenic carbonate with $\mathrm{CaCO}_{3}$. In this study, the absolute abundance and species diversity of fauna in the sediment fraction of $>63 \mu \mathrm{m}$ in weight $\%$ of total sediment. In addition, the state of preservation of foraminiferal tests was noted in the samples. Benthic foraminiferal species Uvigerina hispida-costata, Oridorsalis umbonatus and Quinqueloculina spp to understand changes in deep-sea organic carbon and oxygen content. Approximately 100-300 specimens of benthic foraminifera were picked from a suitable sample and their diversity and distribution were calculated (Table 1).

\section{General Setting}

Sampling stations are, at present located in subtropical waters. In the present-day locations, is bathed by lowoxygen and relatively productive deep waters of the northern Indian origin deep-sea benthic foraminife raprovides useful information on the influence of various deep-water masses in the region. The physico-chemical properties of the surface waters in the western Indian Ocean are strongly influenced by African through flow water because of substantial export of freshwater and heat from the Pacific into the Indian Ocean through the Indian seas. At present, the area is influenced by the summer monsoon winds producing major divergence and an open-ocean upwelling. In the present-day ocean, the in situ primary production in the surface waters is between 200 and $300 \mathrm{mg}$ during the summer monsoon, which is reduced during the winter monsoon.

Table 1. Benthic foraminiferal species number with depth (m).

\begin{tabular}{|c|c|c|c|c|c|}
\hline \multirow{2}{*}{ S.No. } & \multirow{2}{*}{ Species } & \multicolumn{4}{|c|}{ Depth $(\mathrm{m})$} \\
\hline & & 3150 & 3465 & 3790 & 4125 \\
\hline 1 & Marginopora vertibralis & 164 & & & \\
\hline 2 & Sorites marginalis & 131 & & & \\
\hline 3 & Borelis schlumbergeri & 152 & & & \\
\hline 4 & Heterostegina depressa & 140 & & & \\
\hline 5 & Elphidium crispum & 131 & & & \\
\hline 6 & Ammonia tepida & 129 & & & \\
\hline 7 & Quinqueloculina parkeri & 153 & & & \\
\hline 8 & Spirillina decorata & 146 & & & \\
\hline 9 & Textularia sagittula & 133 & & & \\
\hline 10 & Eponides repandus & 136 & & & \\
\hline 11 & Calcarina calcar & 166 & & & \\
\hline 12 & Gyroidina sp. & 156 & & & \\
\hline 13 & Pyrgo murrhina & 145 & & & \\
\hline 14 & Bulimina alazanensis & 135 & & & \\
\hline 15 & Pullenia subcarinata & 148 & & & \\
\hline 16 & $\begin{array}{l}\text { Discopulvinulina } \\
\text { bertheloti }\end{array}$ & 164 & & & \\
\hline 17 & Epistominella exigua & 281 & 292 & & \\
\hline 18 & Pullenia bulloides & 136 & 156 & & \\
\hline 19 & Gyroidina neosoldani & & 145 & & \\
\hline 20 & $\begin{array}{l}\text { Astrononion umbilica- } \\
\text { tulum }\end{array}$ & & 142 & & \\
\hline 21 & Planulina wuellerstorfi & & & 132 & \\
\hline 22 & Oolina apiculata & & & 163 & \\
\hline 23 & Oolina desophora & & & 155 & \\
\hline 24 & Laticarinina pauperata & & & 145 & \\
\hline 25 & Fissurina sp. & & & 165 & \\
\hline 26 & Fissurina alveolata & & & 148 & \\
\hline 27 & Nummoloculina sp. & & & 156 & \\
\hline 28 & Pullenia quinqueloba & & & 148 & \\
\hline 29 & Lagena stelligera & & & 158 & \\
\hline 30 & Oridorsalis umbonatus & 286 & & 278 & \\
\hline 31 & Melonis sphaeroides & 279 & & 214 & \\
\hline 32 & $\begin{array}{l}\text { Chilostomella } \\
\text { ovoidea }\end{array}$ & & & & 153 \\
\hline 33 & Uvigerina hispida & & & & 289 \\
\hline 34 & $\begin{array}{l}\text { Uvigerina his- } \\
\text { pido-costata }\end{array}$ & & & & 163 \\
\hline 35 & Eggerella bradyi & & & & 180 \\
\hline 36 & Karreriella bradyi & & & & 163 \\
\hline
\end{tabular}




\section{Ecological Preference of Foraminiferal Proxies Used}

The study of benthic foraminifera is very useful in interpreting the changes in deep-sea environment. They are the longest biomass present at the lower $(>1000 \mathrm{~m})$ and abyssal depths in the modern oceans and are the dominant carbonate tests to be preserved in the deep sea sediments. Many benthic species have separate stratographic ranges and their evolutionary and migratory patterns provide significant biostratigraphic and paleo-ecological information about the deep-sea environments [19].

Uvigerina hispido-costata preferentially occupies the uppermost surface centimeter of organic rich sediments feeding on sediment aggregates, algal remains, and bacteria having highest abundance in the lower part of the OMZ below upwelling areas reflecting a preference for suboxic or dysoxic conditions in the pore bottom water [20]. This species has highest population at water depths between $\sim 300$ and $800 \mathrm{~m}$ with insitu temperature 10$15^{\circ} \mathrm{C}$ and low oxygen. This species has been used as an indicator species for deepening/shoaling of the OMZ base in the northern Arabian Sea [21]. The large abundance of $U$. perigrina in the lower part of the OMZ or below indicate adaptation of this species to degraded organic matter [21]. Oridorralis umbonatus is a cosmopolitan taxon or lower bathyal and abyssal faunas in the Indian [22]. The Atlantic [23] and Antarctic oceans [24] and is often found associated with Antarctic bottom water (AABW) [22]. This species has been reported to indicate a well oxygenated and low organic carbon environment [25]. This species was probably of southern origin with a strongly pulsed food supply and carbonate preservation in an overall oligitrophic environment in the eastern Indian [26]. O. umbonatus reflects low organic carbon and higher carbonate saturation levels of bottom waters in the Sulu Sea [27]. Quinqueloculina is a cosmopolitan miliolid group found between $800-5000 \mathrm{~m}$ water depths in the Indian Ocean [28]. The persistence occurrence of milioliods in the Arabian sea indicates an overall better oxygenation of benthic environment and thus this group can be regarded as a sensitive oxygen marker and its population a toll for reconstructing past climatic changes in bottom water oxygenation [29]. Higher abundance of miliolid group in sediments deposited during glacial intervals under higher-salinity conditions in the northern Red Sea. Miliolids in general, are rare or absent oxygen deferent environments [13]. Bulimina alzaninsis is an intermediate to deep in faunal $(>2 \mathrm{~cm})$ species in the Sulu sea and is dominant at bathyal depths (1500-2000 m) just below the Arabian sea OMZ [30].

\section{Discussion}

In the Indian Ocean, changes in benthic foraminiferal po- pulations have occurred at orbital time scales and have been related to changes in the Indian monsoons [31]. More recently, [2] used environmental preferences of various benthic foraminiferal assemblages and related them to change in seasonality in the Indian Ocean monsoon during the Plio-Pleistocene. In the present study, we attempt to understand paleoceanographic changes in the southeastern Indian Ocean using multivariate analysis of deep-sea benthic foraminiferal census data from south western sampling stations (Figure 1). The interpretations are based on recent environmental preferences of various benthic foraminiferal taxa observed in the Indian as well as abroad.

Deep-sea benthic foraminifera have been used to understand changes in deep water condition driven by climate forcing during the Pliocene and Pleistocene [29]. Several studies have been shown the relationship between benthic faunal composition, productivity of the overlying waters and organic flux to the sea floor [12]. Others suggested oxygen and food supply are the main factors controlling the spatial and in-sediment distribution of benthic foraminifera [29]. This group explains seasonal fluctuations in primary production [5]. Thus benthic foraminifera are considered useful for estimating paleoecology and they are also more resistant to digenetic change compared to planktic foraminifera. However, in oligotrophic areas deep-sea oxygenation plays an important role in controlling benthic foraminifera over different time scales. It is believed that changes in oxygenation are linked partially to productivity and partially to changes in deep-water ventilation [3]. Wind driven coastal and open-ocean surface productivity influences organic carbon flux and oxygenation of deep waters controlling benthic populations in the Arabian Sea. In the Northern part of the Indian Ocean, the wind regimes follow seasonal changes in circulation producing wide spread upwelling controlling surface productivity. Because of the sampling locations in oligotrophic areas

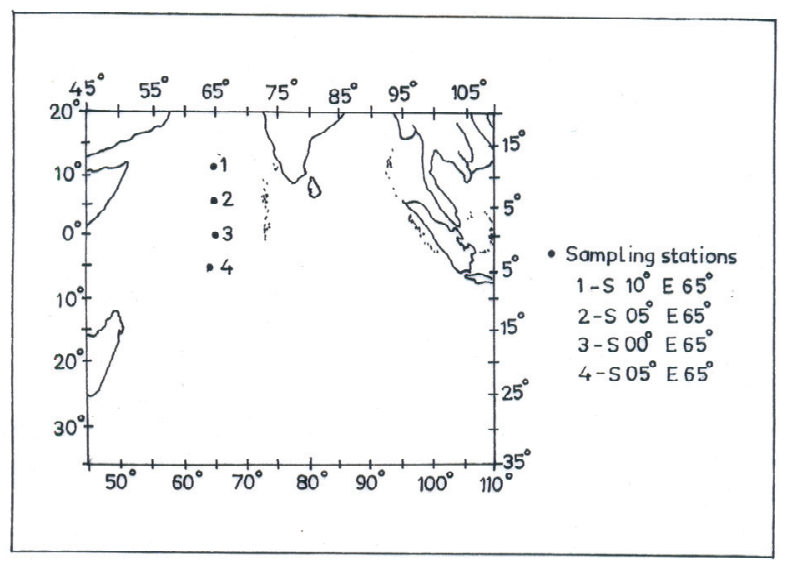

Figure 1. Map showing sampling locations in the tropical Indian Ocean. 
with high dissolved oxygen content during the studies period, the changes in benthic foraminiferal population might have been linked to the supply of organic food.

\section{Results}

The absolute abundances (number of specimens per gram bulk sediment) of benthic foraminifera fluctuate largely. A total of 36 species of benthic foraminifera were recognized comprising predominantly of small calcareous species. In the samples $(3150 \mathrm{~m}, 3465 \mathrm{~m}, 3790 \mathrm{~m}$ and $4125 \mathrm{~m}$ water depth) used in the benthic foraminiferal distribution, the abundant species occur in sample $3150 \mathrm{~m}$ are Gyroidina sp, Pyrgo murrhina, Bulimina alazanensis Pullenia subcarinata, Discopulvinulina bertheloti, Epistominella exigua and Pullenie bulloides; at sample 3465 $\mathrm{m}$ depth are Epistominella exigua, Pullenia bulloides, Gyroidina neosoldani and Astrononion umbilicatalum; at sample $3790 \mathrm{~m}$ depth are Planulina wullerstorfi, Oolina apiculata, Oolina desophora, Laticarinina pauperata, Fissurina alveolata, Nummoloculina sp, Pullenia quinqueloba, Lagena stelligera, Oridorsalis umbonatus, Melonis sphaeroides and Chilostomella ovoidea at sample $4125 \mathrm{~m}$ water depths are Uvigerina hispido-costata, Eggerella bradyi and Karreriella bradyi.

\section{Factor Analysis}

The foraminiferal data census of 10 species was subjected to the factor analysis. The analysis yield three factors namely Factor 1 (37.11\%), Factor 2 (25.87\%) and Factor $3(10.83 \%$ ) accounting for $72.81 \%$ (Table 3 ).

\section{Factor 1}

Factor 1 represented by Uvigerina hispida (0.827), Eggerella bradyi (0.827), Epistominella exigua (-0.796) and Pullenia bulloides (0.766). Uvigerina hispida relates continuous, high organic flux, low seasonality. Eggerella bradyi reflects cool, carbonate corrosive organic flux, variable and high oxygenation [8].

Factor 2

Factor 2 is dominated by Gyroidina neosoldani (0.984), Astrononion umbilicatulum (-0.984); Oridorsalis umbonatus (0.713) and Melonis sphaeroides (0.700). This factor indicates intermediate organic flux, intermediate to high seasonality, high-moderate organic flux, intermediate high seasonality, refractory organic matter. However, Oridorsalis umbonatus tend to reflect relatively warm intermediate organic flux, intermediate seasonality, and moderate oxygenation [8].

Factor 3

Factor 3 comprises of Calcarina calcar $(-0.465)$, Oridorsalis umbonatus (0.364) and are Epistominella exigua $(-0.306)$. Three species indicate cool strongly pulsed, low to intermediate organic flux, high seasonality. In addition, relatively warm intermediate organic flux, intermediate seasonality, moderate oxygenation is also reflected.

A cross plot of Factors $1 \& 2$ and Factors $1 \& 3$ gives district information of faunal assemblages a set clustered similar factor. Pearson correlation matrix of dominated species (Table 2) shows the distinct positive and negative correlation with a specific species. Calcarina calcar and Gyroidina sp shows high positive relation with Melonis sphaeroides (0.717), Oridorsalis umbonatus (0.594), Epistominella exigua (0.555). Epistominella exigua and Pullenia bulloides correlated positively with Pullenia bulloides (0.998), Gyroidina neosoldani (0.599) and Astrononion umbilicatulum (0.599). Where as Gyroidina neosoldani, Astrononion umbilicatulum, Oridorsalis umbonatus, Melonis sphaeroides shows negative correlation with other species (Table 2). The vertical distribution of living benthic foraminifera within the sediment is controlled largely by a combination of oxygen content and organic carbon levels $[4,13]$. In eutrophic regions, oxygen decreases close to the sediment surface and becomes a limiting factor, favouring low-

Table 2. Pearson correlation matrix of 10 dominant species.

\begin{tabular}{|c|c|c|c|c|c|c|c|c|c|c|}
\hline Variables & $\begin{array}{c}\text { Calcarina } \\
\text { calcar }\end{array}$ & $\begin{array}{l}\text { Gyroid- } \\
\text { ina sp. }\end{array}$ & $\begin{array}{c}\text { Epistominella } \\
\text { exigua }\end{array}$ & $\begin{array}{c}\text { Pullenia } \\
\text { bulloides }\end{array}$ & $\begin{array}{l}\text { Gyroidina } \\
\text { neosoldani }\end{array}$ & $\begin{array}{c}\text { Astrononion } \\
\text { umbilicatulum }\end{array}$ & $\begin{array}{l}\text { Oridorsalis } \\
\text { umbonatus }\end{array}$ & $\begin{array}{c}\text { Melonis } \\
\text { sphaeroides }\end{array}$ & $\begin{array}{c}\text { Uvigerina } \\
\text { hispida }\end{array}$ & $\begin{array}{c}\text { Eggerella } \\
\text { bradyi }\end{array}$ \\
\hline Calcarina calcar & 1 & & & & & & & & & \\
\hline Gyroidina sp. & 1.000 & 1 & & & & & & & & \\
\hline $\begin{array}{l}\text { Epistominella } \\
\text { exigua }\end{array}$ & 0.555 & 0.555 & 1 & & & & & & & \\
\hline Pullenia bulloides & 0.496 & 0.496 & 0.998 & 1 & & & & & & \\
\hline $\begin{array}{l}\text { Gyroidina neo- } \\
\text { soldani }\end{array}$ & -0.333 & -0.333 & 0.599 & 0.653 & 1 & & & & & \\
\hline $\begin{array}{l}\text { Astrononion } \\
\text { umbilicatulum }\end{array}$ & -0.333 & -0.333 & 0.599 & 0.653 & 1.000 & 1 & & & & \\
\hline $\begin{array}{l}\text { Oridorsalis um- } \\
\text { bonatus }\end{array}$ & 0.594 & 0.594 & -0.005 & -0.055 & -0.577 & -0.577 & 1 & & & \\
\hline $\begin{array}{l}\text { Melonis sphaer- } \\
\text { oides }\end{array}$ & 0.717 & 0.717 & 0.108 & 0.053 & -0.568 & -0.568 & 0.987 & 1 & & \\
\hline Uvigerina hispida & -0.333 & -0.333 & -0.577 & -0.575 & -0.333 & -0.333 & -0.577 & -0.568 & 1 & \\
\hline
\end{tabular}


Table 3.Factor loading scores for 10 dominant species.

\begin{tabular}{lrrr}
\hline \multicolumn{1}{c}{ Species } & \multicolumn{1}{c}{ F1 } & \multicolumn{1}{c}{ F2 } & \multicolumn{1}{c}{ F3 } \\
\hline Calcarina calcar & $\mathbf{- 0 . 7 8 6}$ & 0.408 & -0.465 \\
Gyroidina sp. & $\mathbf{- 0 . 7 8 6}$ & 0.408 & -0.465 \\
Epistominella exigua & $\mathbf{- 0 . 7 9 6}$ & -0.522 & -0.306 \\
Pullenia bulloides & $\mathbf{- 0 . 7 6 6}$ & -0.579 & -0.281 \\
Gyroidina neosoldani & -0.146 & $\mathbf{- 0 . 9 8 4}$ & 0.100 \\
Astrononion umbilicatulum & -0.146 & $\mathbf{- 0 . 9 8 4}$ & 0.100 \\
Oridorsalis umbonatus & -0.600 & $\mathbf{0 . 7 1 3}$ & 0.364 \\
Melonis sphaeroides & -0.679 & $\mathbf{0 . 7 0 0}$ & 0.220 \\
Uvigerina hispida & $\mathbf{0 . 8 2 7}$ & 0.161 & -0.539 \\
Eggerella bradyi & $\mathbf{0 . 8 2 7}$ & 0.161 & -0.539 \\
\hline
\end{tabular}

oxygen species. In oligotrophic areas, most of the organic matter is remineralized near the sediment surface and the sediment is well oxygenated to a significant depth. Such environments are foodlimited and favour epifaunal species, which are intolerant of low oxygen concentrations. [5] suggested that the dynamics of foraminiferal populations can be explained by the interplay between food and oxygen availability. For example, in eutrophic environments population fluctuations will be driven mainly by changes in both food and oxygen availability whereas in food-limited (oligotrophic) systems the populations will be driven solely by changes in the food supply [14]. It has been found that some species of benthic foraminifera are opportunistic and prefer to feed on seasonal fluxes of organic matter in overall oligotrophic central oceanic areas or seasonally upwelling areas on continental margins [32]. The non-opportunists thrive during sustained supply of organic particles [6,32]. Besides, certain species have a preference to decayed organic matter that reaches the seafloor $[4,21]$.

The vertical distribution of benthic foraminifera in Indian Ocean is given in Table 2. A total of 36 species of benthic foraminifera were recognized comprising predominantly of small calcareous species from western Indian Ocean and 11 larger benthic species from Mauritius. The table shows that species like Epistominella exigua and Pullenia bulloides occur at both $3150 \mathrm{~m}$ and $3465 \mathrm{~m}$ depths indicating depth persistence. Epistominella exigua is an epibenthic, cosmopolitan, abyssal species, which feeds opportunistically on phytodetritus deposited seasonally on the sea floor [11]. It is suggested that this species is most abundant at highly seasonal food fluxes that occur more than once a year (e.g., spring and fall blooms; [14]). Futhermore, Oridorsalis umbonatus and Melonis sphaeroides occur at both 3150 and $3740 \mathrm{~m}$ depths indicating shelf fauna. species like Gyroidina spp an indicative of low oxygen environment and Uvigerina hispido-costata indicate high organic carbon are found to occur at $3150 \mathrm{~m}$ and $4125 \mathrm{~m}$ respectively. Changes in open-ocean surface productivity, linked to the wind regimes and major surface currents, influence the organic carbon fluxes and oxygenation of deep waters and thus benthic populations. Samplings Sites has moved from a temperate to subtropical position through the Miocene and is suitable to understand the effect of this northward movement on deep-sea fauna. The benthic foraminiferal vertical distributional pattern indicates important shifts in the character and amount of organic carbon flux and in oxygenation of deep waters at stations. This study suggests that benthic ecosystem variability in the deep Indian Ocean is not only driven by variations in monsoonal upwelling and related organic matter flux but also by changes in deeper water ventilation; increased summer monsoon circulation may not always result in an oxygen poor deep ocean with increased to total organic carbon (TOC) accumulation.

\section{Conclusions}

1) Benthic foraminiferal faunal distribution and species is erratic and appears to be influenced by availability of nutrients and oxygen content during seasonal upwelling (Table 4).

2) Changes in the abundance and diversity of benthic foraminiferal fauna are likely caused by variations in seasonal upwelling on the ocean floor at the sampling site.

3) The foraminiferal data show that it's relatively well oxygenated OMZ where the influence of intense monsoon-related production was migrated.

4) The high variability in the tropical deep-sea environments occurred at a time when the earth's climate was exploring large scale turnovers due to the increased intensity of glacial-interglacial cycles (Table 4).

\section{Acknowledgements}

We thank students for providing the samples used in this

Table 4. Benthic foraminiferal species and bio faces.

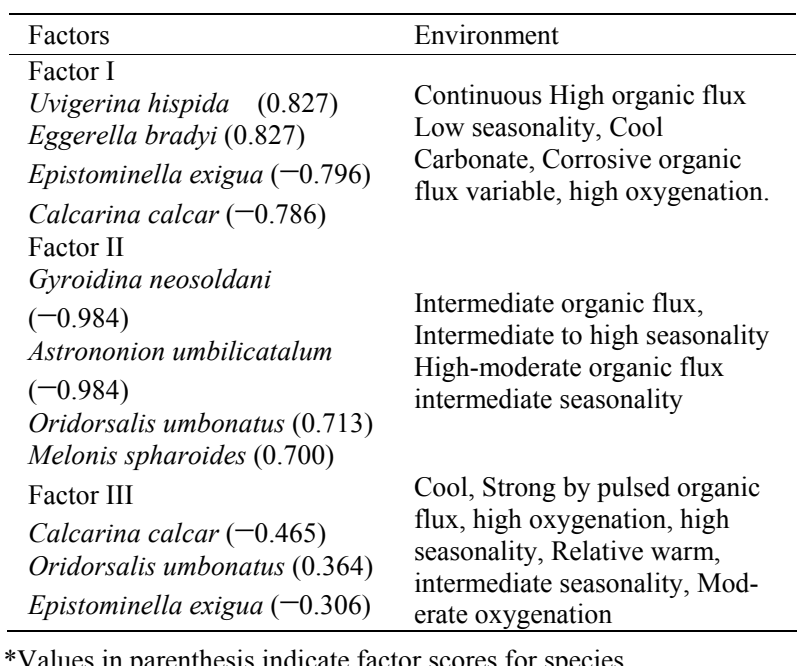

*Values in parenthesis indicate factor scores for species. 
study, collected from Indian Ocean expedition organized by National Center for Antarctica and Ocean Research (NCAOR), in Sagar Kanya, 2009. The very useful comments of the anonymous reviewers significantly improved the manuscript and are grateful acknowledged. SEM microphotographs are taken at Oil Natural Gas Corporation, Regional Labs, Chennai, India. Thanks are due to Prof A. R. Reddy, Vice-Chancellor, Yogi Vemana University, Kadapa for encouragement.

\section{References}

[1] D. Kroon, T. N. F. Steens and S. R. Froelstra, "Onset of Monsoonal Related Upwelling in the Western Arabian Sea as Revealed by Plantonic Foraminifera," In: W. L. Prell, N. Niitsuma, et al., Eds., Proceedings of the Ocean Drilling Program, Scientific Results, College Station, Texas, Vol. 117, 1991, pp. 257-264.

[2] A. K. Gupta, D. M. Anderson and T. J. Overpeck, "Abrupt Changes in the Asian South West Monsoon during the Holocene and their Links to the North Atlantic Ocean," Nature, Vol. 421, No. 6921, 2003, pp. 354-356.

[3] A. K. Gupta and E. Thomas, "Latest Miocene through Pleistocene Paleoceanography, Evolution of the NW Indian Ocean (DSDP Site 21); Global and Regional Factors," Paleooceanography, Vol. 14, No. 1, 1999, pp. 111-124.

[4] B. H. Corliss, "Recent Deep-Sea Benthic Foraminiferal Distribution in the South Eastern Indian Ocean: Inferred Bottom Water Recites and Ecological Implications," $\mathrm{Ma}$ rine Geology, Vol. 31, No. 1-2, 1979, pp. 115-138.

[5] A. J. Gooday, "Ephifaunal and Shallow Infaunal Foraminiferal Communities at Three Abyssal NE Atlantic Sites Subject to Differing Phytodetritus Input Regimes," Deep-Sea Research, Vol. 43, No. 9, 1996, pp. 1395-1421.

[6] J. Zachos, M. Pagni, L. Sloan, E. Thomas and K. Bilheps, "Trends, Rhythms and Abbreviations in Global Climate 65 Ma to Present," Science, Vol. 292, No. 5517, 2001, pp. 686-693.

[7] G. H. Hang and R. Tidemanm, "Effect of the Formation of the Isthmus of Panama on Atlantic Ocean Therohaline Circulation," Nature, Vol. 393, No. 6686, 1998, pp. 673-676.

[8] A. K. Gupta, R. K. Singh, S. Joseph and E. Thomas, "Indian Ocean High Productivity Event (10-8 Ma): Linked to a Global Cooling or to the Incitation of the Indian Monsoons?" Geology, Vol. 32, No. 9, 2004, pp. 753-756.

[9] C. S. Hernoylion and R. M. Owen, "Late Miocene-Early Pliocene Biogenic Bloom: Evidence from Low-Productivity Regions of the Indian and Atlantic Oceans," $\mathrm{Pa}$ leogeography, Vol. 16, No. 1, 2001, pp. 95-100.

[10] E. Thomas and A. J. Gooday, "Cenozoic Deep-Sea Benthic Foraminifers: Tracers for Changes in Oceanic Productivity," Geology, Vol. 24, No. 4, 1996, pp. 355-358.

[11] A. K. Gupta, M. Sundar Raj, K. Mohan and D. Soma, “A Major Change in Monsoon - Driven Productivity in the Tropical Indian Ocean during Ca 1.2-0.9 Mys: Fora- miniferal Faunal and Stable Isotope Data," Paleogeography, Paleoclimatology, Paleoecology, Vol. 261, No. 3-4, 2008, pp. 234-245.

[12] C. W. Smart, E. Thomas and A. T. S. Ramsay, "Middle-Late Miocene Benthic Foraminifera in a Western Equatorial Indian Ocean Depth Transect: Paleoocenographic Implications," Paleogeography, Paleoclimatology, Paleoecology, Vol. 247, No. 3-4, 2007, pp. 402-420.

[13] F. J. Jorissen, H. C. Destigter and J. Widemark, "A Conceptual Model Explaining Benthic Foraminiferal Microhabitats," Marine Micropaleontology, Vol. 26, No. 1, 1995, pp. 3-15.

[14] G. Schmiedl and A. Mackensen, "Multi Species Stable Isotopes of Benthic Foraminifers Revels Past Changes of Organic Matter Decomposition and Deep Water Oxygenation in the Arabian Sea," Paleooceangraphy, Vol. 21. 2006, p. 11.

[15] A. R. Loeblich and H. Tappan, "Foraminiferal Genera and their Classification," Van Nostrand Rinhold Camp, New York, 1987.

[16] T. G. Gibson and W. M. Walker, "Floatation Methods for Obtaining the Foraminifera from Sediment Samples," Jour au Paléo, Vol. 41. No. 5. 1967, pp. 1294-1297.

[17] N. Jayaraju, B. C. Sudara Raja Reddy and K. R. Reddy, "Anthropogenic Impact on Andaman Coast Monitoring with Benthic Foraminifera, Andaman Sea, India," Environmental Earth Science, Vol. 183, 2010, pp. 1049-1052.

[18] R. K. Singh, and A. K. Gupta, "Systematic Decline in Benthic Foraminiferal Species Diversity Linked to Productivity Increases over the Last $26 \mathrm{MA}$ in the Indian Ocean," Journal of Foraminiferal Research, Vol. 35, No. 3, 2005, pp. 219-229.

[19] K. R. Ajay and M. S. Srinivasan, "Pleistocene Oceanographic Changes Indicated by Deep-Sea Benthic Foraminifera in the Northern Indian Ocean," Proceedings of Indian Academic Sciences, Vol. 103, No. 4, 1995, pp. 499-517.

[20] G. Schmiedl and D. C. Lenschrer, "Oxygenation Changes in the Deep Western Arabian Sea during the Last 190,000 Years: Productivity versus Deep-Water Circulation," $\mathrm{Pa}$ leoocenography, Vol. 20, No. 2, 2005, pp. 1-14.

[21] N. T. Jannik, W. J. Zachariasse and G. J. Van Deer Zwaan, "Living (Rose Bengal Stained) Benthic Foraminifera from the Pakistan Continental Margin (Northern Arabian Sea)," Deep-Sea Research, Vol. 45, No. 9, 1998, pp. 1483-1513.

[22] B. H. Corliss, "Recent Deep-Sea Benthic Foraminiferal Distribution in the South Eastern Indian Ocean: Inferred Bottom Water Recites and Ecological Implications," Marine Geology, Vol. 31, No. 1-2, 1979, pp. 115-138.

[23] S. S. Streeter and N. J. Shackleton, "Paleocirculation of the Deep North Atlantic: 150,000 Year Record of Benthic Foraminifera and Oxygen-18," Science, Vol. 203, No. 4376, 1979, pp. 168-171.

[24] T. Uchio, "Biological Results of the Japanese Antarctic Expedition, Benthonic Foraminifera of the Antarctic 
Ocean," Special Publication, Walkayama, Vol. 12, 1960, pp. 21.

[25] A. Mackensen, G. Schimiedl, J. Harlogg and M. Giese, "Deep-Sea Foraminifera in the South Atlantic Ocean: Ecology and Assemblage Generation," Micropaleontology, Vol. 41, No. 4, 1995, pp. 342-358.

[26] R. K. Singh and A. K. Gupta, "Systematic Decline in Benthic Foraminiferal Species Diversity Linked to Productivity Increases over the Last $26 \mathrm{MA}$ in the Indian Ocean," Journal of Foraminiferal Research, Vol. 35, No. 3, 2005, pp. 219-229.

[27] Q. Miao and R. C. Thunell, "Recent Deep-Sea Benthic Foraminiferal Distribution in the South China and Sulu Seas," Marine Micropaleontology, Vol. 22, 1993, pp. $1-32$.

[28] A. K. Gupta, "Taxonomy and Bathymetric Distribution of Holocene Deep-Sea Benthic Foraminifera in the Indian Ocean and Red Sea," Micropaleontology, Vol. 40, No. 4, 1994, pp. 351-367.
[29] M. Den Dulk, G. J. Reichart, S. Van Heyst, W. J. Zachariasse and G. J. Vander Zewaan, "Benthic Foraminifera as Proxies of Organic Mater Flux and Bottom Water Oxygenation? A Case History from the Northern Arabian Sea," Paleogeography, Paleoclimatology, Paleoecology, Vol. 161, No. 3, 2000, pp. 337-359.

[30] J. O. R. Hermelin and G. B. Shimmield, "The Importance of the Oxygen Minimum Zone and Sediment Geochemistry on the Distribution of Recent Benthic Foraminiferal from the Northwestern Indian Ocean," Marine Geology, Vol. 91, No. 1-2, 1990, pp. 1-29.

[31] A. K. Gupta, S. Joseph and E. Thomas, "Species Diversity of Miocene Deep-Sea Benthic Foraminifera and Waters mass Stratification in the North Eastern Indian Ocean," Micropaleontology, Vol. 47, No. 2, 2001, pp. 111-124.

[32] E. Thomas and A. J. Gooday, "Cenozoic Deep-Sea Benthic Foraminifers: Tracers for Changes in Oceanic Productivity?" Geology, Vol. 24, No. 4, 1996, pp. 355-358. 